\title{
Serum Epidermal Growth Factor Receptor and p53 in Patients with Acute Myeloid Leukemia
}

\author{
MADONNA M. EL-TOUKHY, M.B.B.Ch.*; HEBA A.M. MORAD, M.D.*; HOSSAM A. HODIB, M.D.* and \\ WAEL F. MOHAMED FARRAG, M.D.** \\ The Departments of Clinical Pathology* and Internal Medicine**, Faculty of Medicine, Tanta University
}

\begin{abstract}
Background: Acute myeloid leukemia is a clonal hematopoietic disorder that may be derived from either a hematopoietic stem cell or a lineage-specific progenitor cell. AML is characterized both by a predominance of immature forms and loss of normal hematopoiesis. p53 is a cell cycle check point control protein that detects DNA damage, controls cell growth, DNA repair and apoptosis. EGFR belongs to a family of receptor tyrosine kinases, it plays an important role in many cancers. Since both markers have a role in cell cycle control, we hypothesized that both p53 and EGFR may have a role in AML.
\end{abstract}

Aim of Study: It was to estimate the levels of p53 and EGFR in the serum of patients with AML.

Patients and Methods: The study was carried out on forty newly diagnosed AML patients who were selected from Hemato-Oncology Unit, Internal Medicine Department, Tanta University Hospitals. Also on twenty apparently healthy subjects with matched age and sex served as a control group. All studied subjects were subjected to full history, complete physical examination, estimation of p53 and EGFR levels by ELISA. Data was analyzed by using SPSS.

Results: The results demonstrated a significant increase of serum p53 and EGFR levels in AML patients group compared to control group. A positive significant correlation was noted between p53 and EGFR. Follow-up of patients' group for 18 months revealed that all patients with low p53 and EGFR levels showed good response to therapy and achieved complete remission while patients with high p53 and EGFR levels showed poor outcome.

Conclusion: Estimation of both p53 and EGFR levels could be useful as diagnostic and prognostic biomarkers in AML patients either alone or in combination with other biomarkers.

Key Words: Acute myeloid leukemia - p53-EGFR serum levels by ELISA.

Correspondence to: Dr. Madonna Mamdouh El-Toukhy, The Department of Clinical Pathology, Faculty of Medicine, Tanta University

\section{Introduction}

ACUTE Myeloid Leukemia (AML) is a form of malignancy that is characterized by infiltration of the bone marrow, blood, and other tissues by proliferative, clonal, abnormally differentiated cells of the hematopoietic system [1].

AML pathogenesis includes genetic changes in hematopoietic progenitor cells altering normal mechanisms of proliferation and differentiation, thus resulting in accumulation of myeloid lineage blast cells in the bone marrow [2]

Blast cells interfere with normal hematopoiesis, contributing to the bone marrow failure, which is the most common underlying cause of mortality [3].

AML is the second most common type of leukemia affecting adults and is responsible for the largest number of leukemia related deaths [4].

The tumor suppressor p53 is often described as "guardian of the genome," activating specific transcriptional targets in response to stress, such as DNA damage and oncogenic events [5]

P53 possesses a range of biological activities that may contribute to its role in tumor suppression, including its ability to trigger various cell cycle checkpoints and apoptosis, so loss of p53 function fuels genomic instability that facilitates tumor evolution [6].

Tumor cells inactivate p53 function via somatic mutations in its tumor suppressor gene leading to loss or diminution of the activity of wild-type p53, increasing mutant protein and give it new activities that contribute actively to various stages of tumor progression and to increased resistance to anticancer treatments [7]. 
The Epidermal Growth Factor Receptor (EGFR) family belongs to type I receptor tyrosine kinases. Over expression or mutation of EGFR gene has been detected in a large number of human tumors [8].

Driven largely by its role in promoting cell proliferation and opposing apoptosis, the EGFR has been verified as a proto-oncogene [9].

\section{Aim:}

It was to evaluate the diagnostic utility of estimation of p53 and EGFR levels in the serum of patients with AML.

\section{Patients and Methods}

The study was conducted on 40 AML cases who were selected from Hemato-Oncology Unit, Internal Medicine Department, Tanta University Hospitals and 20 healthy control cases from June 2016 to January 2018.

\section{Exclusion criteria:}

Patients with malignancy other than AML, patients with chronic diseases, pregnant and lactating females and those unwilling to participate.

Both patients and control groups were subjected to the following: Full history taking, clinical examination, routine investigations included $\mathrm{CBC}$, ESR, LDH, liver and renal function tests, bone marrow aspiration, cytochemical study and immunophenotyping. Specific investigations included serum $\mathrm{p} 53$ and EGFR levels detected by ELISA kits provided by SunRed diagnostics for in vitro diagnosis.

Statistical presentation and analysis of the present study was conducted using the mean, standard deviation, student $t$-test, Chi-square by SPSS V20 with $p<0.05$ means significance.

\section{Results}

This study was conducted on 40 AML cases and 20 healthy individuals, both patients and control were cross matched for age and sex. Table (1) shows the age and gender distribution in both AML patients group and control group. There was no significant difference between both groups as regards age and gender.

AML classification of the studied 40 patients was subdivided from M 1 to M7 according to French American British (FAB) classification as shown in Fig. (1). 4/40 (10\%) were AML-M1, 17/40 (42.5\%) were AML-M2, 7/40 (17.5\%) were AMLM3, 7/40 (17.5\%) were AML-M4, 5/40 (12.5\%) were AML-M5 and non were either AML-M6 or AML-M7.

P53 and EGFR levels were compared between patients and control groups and found that there was a significant increase in p53 and EGFR levels in AML patients group compared to control group with $p=0.001$ as shown in (Table 2).

Correlations between p53 and EGFR levels and age and gender of AML patients group were done as shown in (Table 3). This showed that there was no significant correlation between p53 and EGFR levels and age and gender in AML patients.

Correlations between p53 and EGFR levels and laboratory parameters of AML patients group were done as shown in (Table 4) and showed that there was a significant negative correlation between p53 levels and $\mathrm{Hb}$ levels, while there was a significant positive correlation between p53 levels and $\mathrm{PB}$ blasts, BM blasts, LDH and ESR levels in AML patients.

Correlation between p53 and EGFR levels were done as shown in (Table 5) and showed significant positive correlation between the 2 markers in AML patient group.

Table (6) and Fig. (2) shows the Receiver Operating Characteristic curve (ROC) for p53 which illustrated the diagnostic sensitivity and specificity of p53 in AML patients and control groups, the best cut off level of p53 in discriminating AML patients from healthy subjects was $(160 \mathrm{pg} / \mathrm{ml})$, with an Area Under the Curve (AUC) of (0.98) yielding sensitivity of $82 \%$, specificity of $97.5 \%$, Positive Predictive Value (PPV) (94\%), Negative Predictive Value (NPV) (91\%) and accuracy (92\%).

Table (7), Fig. (3) shows the Receiver Operating Characteristic curve (ROC) for EGFR which illustrated the diagnostic sensitivity and specificity of P53 in AML patients and control groups, the best cut off level of EGFR in discriminating AML patients from healthy subjects was $(100 \mathrm{pg} / \mathrm{ml})$, with an Area Under the Curve (AUC) of (0.97) yielding sensitivity of $85 \%$, specificity of $95.0 \%$, Positive Predictive Value (PPV) (89\%), Negative Predictive Value (NPV) (93\%) and accuracy (92\%).

The 40 AML patients were classified into 35 p53 and EGFR positive patients and 5 p53 and EGFR negative patients. Follow-up of patients' group for 18 months revealed that all 5 negative patients (5/5) (100\%) showed good response to therapy and achieved complete remission while among the 35 positive patients only 9 patients 
(9/35) $(25.7 \%)$ achieved complete remission and the remaining 26 patients (26/35) $(74.3 \%)$ showed poor outcome including treatment resistance, relapse or death as shown in (Table 8).

There was a significant association between p53 and EGFR positive values and poor outcome of AML with $p=0.001$.

\begin{tabular}{|c|c|c|c|c|}
\hline & Patients & Control & Test & $p$-value \\
\hline \multicolumn{5}{|l|}{ Age (years): } \\
\hline Range & $18-63$ & $21-60$ & $t$-test & 0.086 \\
\hline Mean \pm S.D & $46.65 \pm 13.37$ & 40.55 & 3.046 & \\
\hline \multicolumn{5}{|l|}{ Gender: } \\
\hline Male (\%) & $22(55 \%)$ & $12(60 \%)$ & $x^{2}$ & 0.713 \\
\hline Female (\%) & $18(45 \%)$ & $8(40 \%)$ & 0.136 & \\
\hline
\end{tabular}

Table (2): p53 and EGFR levels in AML patients group and control.

\begin{tabular}{cllll}
\hline & \multicolumn{1}{c}{ Range } & \multicolumn{1}{c}{ Mean \pm SD } & $t$-test & $p$-value \\
\hline P53 pg/ml: & & & & \\
Patients & $148.64-2163.55$ & $838.50 \pm 491.55$ & 11.673 & $0.001^{*}$ \\
Control & $49.36-200.11$ & $124.39 \pm 45.68$ & & \\
& & & & \\
EGFR pg/ml: & & & & \\
Patients & $79.88-1139.65$ & $469.56 \pm 267.00$ & 13.478 & $0.001^{*}$ \\
Control & $28.75-114.81$ & $73.26 \pm 26.42$ & & \\
\hline
\end{tabular}

Table (3): Correlation between p53 and EGFR and age and gender of AML patients group.

\begin{tabular}{lccccc}
\hline & \multicolumn{2}{c}{ P53 pg/ml } & & \multicolumn{2}{c}{ EGFR pg/ml } \\
\cline { 2 - 3 } \cline { 5 - 6 } & $r$ & & & $r$ & $p$ \\
\hline Gender & 0.184 & 0.171 & & 0.171 & 0.291 \\
Age & 0.271 & 0.276 & & 0.276 & 0.085 \\
\hline
\end{tabular}

*: Significant at $p \leq 0.05$.

Table (4): Correlation between p53 and EGFR and laboratory parameters in AML patients group.

\begin{tabular}{lcccc}
\hline & \multicolumn{2}{c}{ P53 pg/ml } & \multicolumn{2}{c}{ EGFR pg/ml } \\
\cline { 2 - 5 } & $r$ & $p$ & $r$ & $p$ \\
\hline $\mathrm{Hb}$ & -0.800 & $0.001^{*}$ & -0.791 & $0.001^{*}$ \\
$\mathrm{TLC}$ & -0.275 & 0.086 & -0.256 & 0.110 \\
Platelet & -0.129 & 0.429 & -0.109 & 0.504 \\
Peripheral blasts & 0.957 & $0.001^{*}$ & 0.956 & $0.001^{*}$ \\
BM blasts & 0.936 & $0.001^{*}$ & 0.930 & $0.001^{*}$ \\
LDH & 0.958 & $0.001^{*}$ & 0.960 & $0.001^{*}$ \\
ESR & 0.854 & $0.001^{*}$ & 0.846 & $0.001^{*}$ \\
\hline
\end{tabular}

*: Statistically significant at $p$-value $\leq 0.05$.
Table (5): Correlation between p53 and EGFR in AML patient group.

\begin{tabular}{ccc}
\hline & \multicolumn{2}{c}{$\mathrm{P} 53 \mathrm{pg} / \mathrm{ml}$} \\
\cline { 2 - 3 } & \multicolumn{2}{c}{$r$} \\
\hline EGFR pg/ml & $0.001 *$ & 0.994 \\
\hline
\end{tabular}

Table (6): The sensitivity and specificity of p53 in AML patients group.

\begin{tabular}{lccccccc}
\hline & $\begin{array}{c}\text { Cut } \\
\text { off }\end{array}$ & $\begin{array}{r}\text { AUC Sensi- } \\
\text { tivity }\end{array}$ & $\begin{array}{c}\text { Speci- } \\
\text { ficity }\end{array}$ & PPV & NPV & $\begin{array}{c}\text { Accu- } \\
\text { racy }\end{array}$ \\
\hline $\mathrm{P} 53 \mathrm{pg} / \mathrm{ml}$ & 160 & $\mathbf{0 . 9 8}$ & 82 & 97.5 & 94 & 91 & 92 \\
\hline
\end{tabular}

Table (7): The sensitivity and specificity of EGFR in AML patients group.

\begin{tabular}{lccccccc}
\hline & $\begin{array}{c}\text { Cut } \\
\text { off }\end{array}$ & $\begin{array}{r}\text { AUC Sensi- } \\
\text { tivity }\end{array}$ & $\begin{array}{c}\text { Speci- } \\
\text { ficity }\end{array}$ & PPV & NPV & $\begin{array}{c}\text { Accu- } \\
\text { racy }\end{array}$ \\
\hline EGFR pg/ml & 100 & 0.97 & 85 & 95 & 89 & 93 & 92 \\
\hline
\end{tabular}

Table (8): Clinical outcome of AML patients group.

\begin{tabular}{|c|c|c|c|c|}
\hline \multirow{2}{*}{ Outcome } & \multicolumn{2}{|c|}{ P53 and EGFR } & \multirow{2}{*}{$x^{2}$} & \multirow{2}{*}{$\begin{array}{c}p- \\
\text { value }\end{array}$} \\
\hline & $-\mathrm{ve}$ & $+\mathrm{ve}$ & & \\
\hline \multicolumn{5}{|c|}{ Complete remission: } \\
\hline $\mathrm{N}$ & 5 & 9 & 10.612 & $0.001 *$ \\
\hline$\%$ & $100.0 \%$ & $25.7 \%$ & & \\
\hline \multicolumn{5}{|c|}{ Poor outcome: } \\
\hline $\mathrm{N}$ & 0 & 26 & - & - \\
\hline$\%$ & $0.0 \%$ & $74.3 \%$ & & \\
\hline \multicolumn{5}{|l|}{ Total: } \\
\hline $\mathrm{N}$ & 5 & 35 & & \\
\hline$\%$ & $100.0 \%$ & $100.0 \%$ & & \\
\hline \multicolumn{5}{|c|}{ Chi-square: } \\
\hline$x^{2}$ & & 10.612 & & \\
\hline$p$-value & & $0.001^{*}$ & & \\
\hline
\end{tabular}

*: Significant at $p \leq 0.05$.

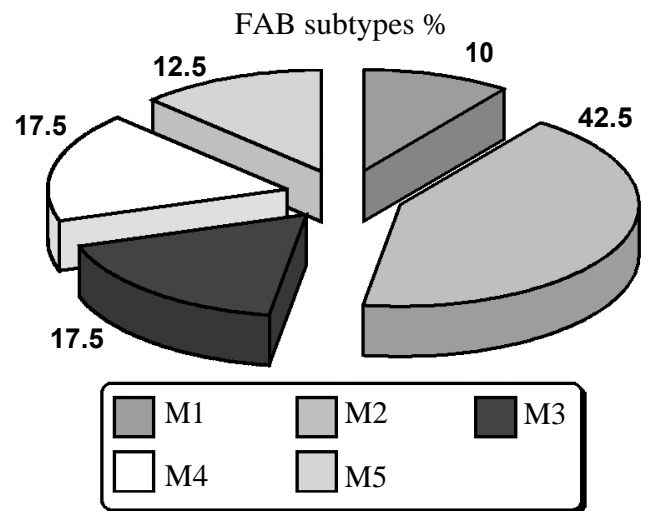

Fig. (1): FAB classification of AML patients. 


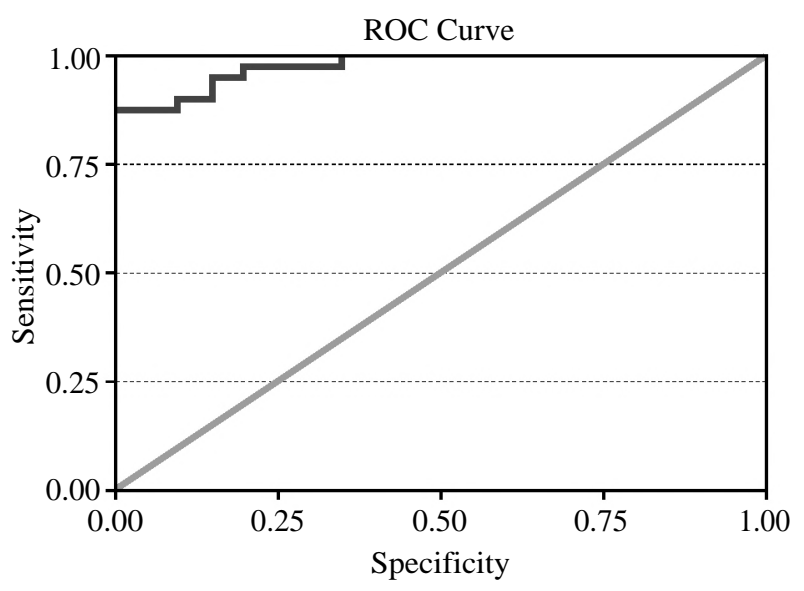

Fig. (2): The (ROC) curve for p53.

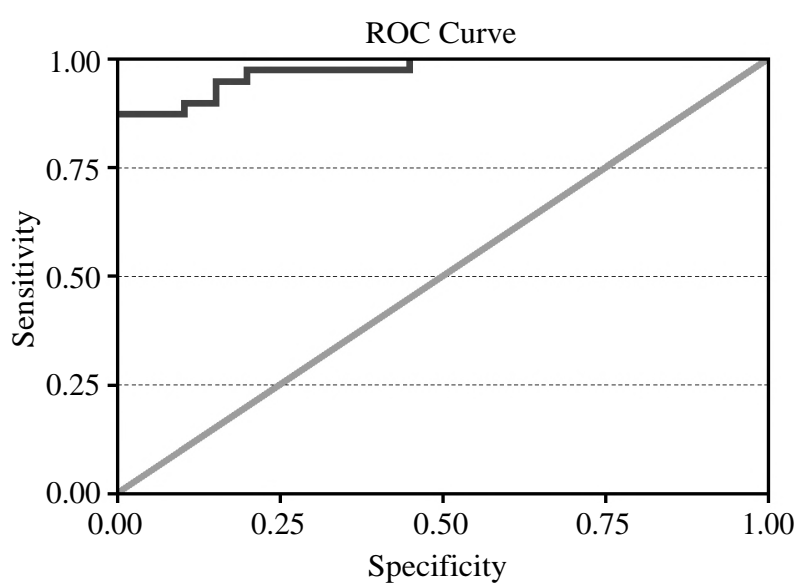

Fig. (3): The (ROC) curve for EGFR.

\section{Discussion}

AML is one of the most common hematological malignancies among adults [10]. P53 is a nuclear transcription factor that is considered to be one of the classical type tumor suppressors. Mutant p53 has an oncogenic potential [11]. EGFR signaling pathway regulates fundamental functions in mammalian cells including survival, migration, proliferation and neo-angiogenesis [12].

This study aimed to evaluate p53 and EGFR levels in AML patients and its association with some clinical and laboratory parameters. In the present work, patients' mean age was 46.65 years. This agreed with Ozek et al., 2004 and Hou et al., 2015 who stated that the mean age of AML is 48 years and 51 years respectively [13,14]. The present results disagreed with studies of Lazarevic et al., 2014 and Pastore et al., 2014 where the median ages were 71 and 60 years respectively $[\mathbf{1 5 , 1 6 ]}$

Regarding patients' gender, there was a predominance of AML in male patients than in females. This may be due to the protective estrogen effect by inducing apoptosis when acting on its Breceptors on hematopoietic cells [17]. The present results were found to be in agreement with Chauhan et al., 2013 whose studies showed that the incidence of AML was slightly higher among males than females [18]. In contrast, Sahu and Jena 2011 found no statistical significance regarding AML patients' characteristics including gender [19]

The FAB classification of the studied 40 AML patients showed that the majority of cases were M2 and no patients were M6 or M7. This agreed with Ozek et al., 2004 and Chang et al., 2016 as majority of patients at their studies were also M2 and no patients were M7 [13,20]. This disagreed with Hasan et al., 2016 who found no significant difference of AML patients as regards FAB classification [21].

In the present work, there was a significant increase in the serum levels of p53 and EGFR in patients with AML. According to the cut off level of p53 and EGFR, the majority of cases showed high levels of both markers and was assigned as p53 and EGFR positive group, while only 5 patients showed low levels of both markers and were assigned as p53 and EGFR negative group. On the other hand, p53 and EGFR levels were low in all individuals of control group compared to patients group. This was in agreement with Sahu and Jena 2011 who stated that $91 \%$ patients with AML were p53 immunopositive using immunocytochemistry [19]. Furthermore, the results of Park et al., 2000 showed that the over expression of $\mathrm{p} 53$ protein was found in $38 \%$ of patients with AML [22].

The present results were also found to be in agreement with the studies of Verhaak et al., 2009 and De Jonge et al., 2010 that detected increased levels of EGFR in AML patients $[23,24]$. Sun et al., 2012, in contrast, stated that EGFR protein levels, as assessed by immuno-chemistry and mRNA levels of EGFR, have been found to be doubtfully low in AML blasts [8]

As regard age and gender, there was no significant difference between p53 and EGFR levels. This was in agreement with Hasan et al., 2016 who stated that there was no significant association between variable levels of p53 and EGFR, and age and gender of AML patients [25]. That disagreed with Duarte et al., 2014 who found a significant difference between p53 expression in both males and females [26].

There was a significant negative correlation between high levels of p53 and EGFR expression and $\mathrm{Hb}$, while a significant positive correlation 
between their levels and LDH, ESR, BM blasts and PB blasts was found. There was no statistical significant correlation between other laboratory data and p53 and EGFR levels including: TLC and platelet count. This is in agreement with AbdelAziz MM., 2013 whose studies revealed that p53 and EGFR expression in AML patients was significantly correlated to $\mathrm{Hb}$ levels [27]. On the other hand, Hasan et al., 2016 found no significant correlation between $\mathrm{Hb}$ levels and EGFR [25]. The present results regarding the correlation between LDH and blast percentage with p53 and EGFR levels were found to be in agreement with Nageswara et al., 2012 who stated that AML patients with p53 polymorphism and high levels of EGFR had elevated levels of LDH and blast percentage [28]. Also Xiong et al., 2009 reported that AML patients in their study with p53 immunopositivity had a higher percentage of blast cells [29]. Hasan et al., 2016 and Sahu and Jena, 2011, on the other hand, found no significant correlation between blast cells percentage and EGFR and p53 expression $[19,25]$

In the current study, significant positive correlation between p53 and EGFR levels was found. This is in agreement with Abdel-Aziz MM. 2013 who stated the same finding [27].

Follow-up of patients' group for 18 months revealed that all 5 negative patients $5 / 5(100 \%)$ showed good response to therapy and achieved complete remission, and non had developed relapse during the follow-up period and they were all found to be M3, while among the 35 positive patients only 9 patients $9 / 35(25.7 \%)$ achieved complete remission and the remaining 26 patients $26 / 35$ (74.3\%) showed poor outcome including treatment resistance, relapse or death.

There was a statistically significant difference between p53 and EGFR positive and negative groups of patients indicating that high p53 and EGFR levels are most probably associated with poor outcome in AML patients. This was in agreement with Meyer and Levine 2014 and Paschka et al., 2015 who stated that mutated Tp53 gene and higher 553 levels in AML was associated with bad prognosis [30,31]. Also Jun-Zhong et al., 2011's studies showed that EGFR positive AML patients had poorer prognosis, they also stated that M3 FAB subtype had the best prognosis [32]. Deangelo et al., 2014, on the other hand, stated that EGFR had no effect on AML patients' outcome [32]. Also Sahu and Jena 2011 stated that a comparison of the p53-positive versus negative subgroup as regard outcome failed to reach statistical significance [19]

\section{Conclusion:}

In this study we could conclude that estimation of both p53 and EGFR levels could be useful as diagnostic and prognostic biomarkers in AML patients either alone or in combination with other biomarkers.

\section{Acknowledgments:}

This research was carried out without funding.

\section{Conflicts of interest:}

No conflicts of interest declared.

\section{Authors' contributions:}

All authors had equal role in design, work, statistical analysis and manuscript writing. All authors have approved the final article work.

\section{References}

1- DOHNER H., ESTEY E.H., AMADORI S., et al.: Diagnosis and management of acute myeloid leukemia in adults: Recommendations from an international expert panel, on behalf of the European Leukemia Net. Blood, 115 (3): 453-74, 2010.

2- SCHLENK R.F.: Post-remission therapy for acute myeloid leukemia. Haematologica, 99: 1663-70, 2014.

3- ESTEY E.H.: Acute myeloid leukemia: 2014 update on risk-stratification and management. Am. J. Hematol., 89: 1063-81, 2014.

4- SIEGEL R., MA J., ZOU Z., et al.: Cancer statistics, CA cancer J. Clin., 64: 9-29, 2014.

5- RETZLAFF M., ROHRBERG J., KUPPER N.J., et al.: The regulatory domain stabilizes the p53 tetramer by inter-subunit contacts with the DNA binding domain. J. Mol. Biol., 425: 144-55, 2013.

6- ALONI-GRINSTEIN R., SHETZER Y., KAUFMAN T., et al.: p53: The barrier to cancer stem cell formation. FEBS Lett., 588: 2580-9, 2014.

7- OREN M. and ROTTER V.: Mutant p53 gain-of-function in cancer. Cold Spring Harb Perspect Biol., 2 (2): a001107, 2010.

8- SUN J.Z., LU Y., XU Y., et al.: Epidermal growth factor receptor expression in acute myelogenous leukaemia is associated with clinical prognosis. Hematol. Oncol., 30: 89-97, 2012.

9- PINES G., KÖSTLER W.J., YARDEN Y., et al.: Oncogenic mutant forms of EGFR: Lessons in signal transduction and targets for cancer therapy. FEBS Lett., 584: 2699706, 2010.

10- O'DONNELL M.R., ABBOUD C.N., ALTMAN J., et al.: Acute myeloid leukemia. Journal Natl. Compr. Canc. Netw., 10: 984-1, 2012.

11- TOSHINORI OZAKI and AKIRA NAKAGAWARA: Role of p53 in Cell Death and Human Cancers, 3 (1): 994-1013, 2011. 
12- ARKHIPOV A., SHAN Y., DAS R., et al.: Architecture and membrane interactions of the EGF receptor. Cell, 152: 557-69, 2013.

13- OZEK K., KIYOI H., HIROSE Y., et al.: Biologic and clinical significance of the FLT3 transcript level in acute myeloid leukemia. Blood, 103: 1901-8, 2004.

14-HOU H.A., CHOU W.C., KUO Y.Y., et al.: TP53 mutations in de novo acute myeloid leukemia patients: Longitudinal follow-ups show the mutation is stable during disease evolution. Blood Cancer Journal, 5: 331, 2015.

15- LAZAREVIC V., HORSTEDT A.S., JOHANSSON B., et al.: Incidence and prognostic significance of karyotypic subgroups in older patients with acute myeloid leukemia, the Swedish population-based experience. Blood Cancer J., 28: 4-188, 2014.

16- PASTORE F., DUFOUR A., BENTHAUS T., et al: Combined molecular and clinical prognostic index for relapse and survival in cytogenetically normal acute myeloid leukemia, J. Clin. Oncol., 20: 1586-94, 2014.

17- ROTA S.G., SPAGNUOLO P.A., ANGKA L., et al.: Estrogen Receptor Beta Is a Novel Target in Acute Myeloid Leukemia. Blood, 126: 1395, 2015.

18- CHAUHAN P.S., IHSAN R., SINGH L.C., et al.: Mutation of NPM1 and FLT3 genes in acute myeloid leukemia and their association with clinical and immunophenotypic features. Dis. Markers, 35: 581-8, 2013.

19- SAHU G. and JENA R.K.: Clinical significance of P53 and Bcl-2 in acute myeloid leukemia patients of Eastern India. Hematol. Rep., 3: 91-4, 2011.

20- CHANG F., SHAMSI T.S. and WARYAH A.M.: Clinical and Hematological Profile of Acute Myeloid Leukemia (AML) Patients of Sindh. J. Hematol. Thrombo. Dis., 4: 2, 2016.

21- HASAN M., STEVEN M.K., ARJA E., et al.: Epidermal growth factor receptor is expressed and active in a subset of acute myeloid leukemia, J. Hematol. Oncol., 9: 64, 2016.

22- PARK J.S., PARK T.H., LIM Y.T., et al.: Clinical significance of p53 protein overexpression and serum anti-p53 antibodies in patients with acute and chronic leukemia. Korean J. Clin. Pathol., 20: 247-54, 2000.

23- VERHAAK R.G., WOUTERS B.J., ERPELINCK C.A., et al.: Prediction of molecular subtypes in acute myeloid leukemia based on gene expression profiling. Haematologica, 94 (1): 131-4, 2009.

24- De JONGE H.J., VALK P.J., VEEGER N.J., et al.: High VEGFC expression is associated with unique gene expression profiles and predicts adverse prognosis in pediatric and adult acute myeloid leukemia. Blood, 9; 116 (10): 1747-54, 2010.

25- HASAN M., STEVEN M.K., ARJA E., et al.: Epiderma growth factor receptor is expressed and active in a subset of acute myeloid leukemia, J. Hematol. Oncol., 9: 64, 2016.

26- DUARTE F.B., GONCALVES R.P., BARBOSA M.C., et al.: Tumor suppressor p53 protein expression: Prognostic significance in patients with low-risk myelodysplastic syndrome. Rev. Bras. Hematol., 63 (3): 196-201, 2014.

27- ABD EL-AZIZ M.M.: Clinical Significance of Serum p53 and Epidermal Growth Factor Receptor in Patients with Acute Leukemia. Asian Pac. J. Cancer Prev., 14 (7): 4295-9, 2013.

28- NAGESWARA R.D., SUGUNAKAR V., SAILAJA K., et al.: TP53 codon 72 polymorphism and risk of acute leukemia, Asian Pacific Journal of Cancer Prevention, 13: 349, 2012.

29- XIONG X., WANG M., WANG L., et al.: Risk of MDM2 SNP309 alone or in combination with the p53 codon 72 polymorphism in acute myeloid leukemia. Leukemia Research, 33: 1454-8, 2009.

30- MEYER S.C. and LEVINE R.L.: Translational implications of somatic genomics in acute myeloid leukaemia. Lancet Oncol., 15 (9): 382-94, 2014.

31- PASCHKA P., SCHLENK R.F., GAIDZIK V.I., et al.: ASXL1 mutations in younger adult patients with acute myeloid leukemia: A study by the German-Austrian Acute Myeloid Leukemia Study Group. Haematologica, 100 (3): 324-30, 2015.

32- JUN-ZHONG S., YING LU, YIN XU, et al.: Epidermal growth factor receptor expression in acute myelogenous leukaemia is associated with clinical prognosis, hematological oncology, 30: 89-97, 2011.

33- DEANGELO D.J., NEUBERG D., AMREIN P.C., et al.: A phase II study of the EGFR inhibitor gefitinib in patients with acute myeloid leukemia. Leuk. Res., 38: 430-4, 2014. 


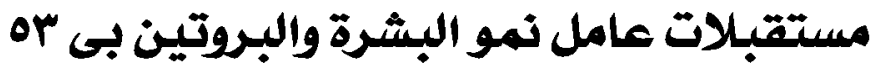

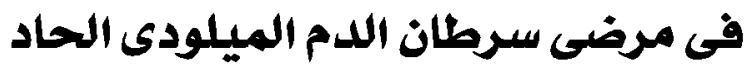

سرطان الدم الميلودى الحاد عبارة عن مجموعة غير متجانسة من الآمراض التى تتميز بتكاثر غير منتظم لخايا دموية آولية خبيثة لتحل

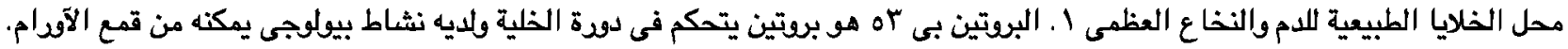

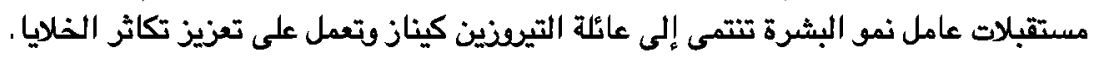
الهدف من الدراسة: هو تقييم مستوى البروتين بى كه ومستقبلات عامل نمى البشرة فى مصل الدم لمرضى سرطان الدم الميلودى الحاد.

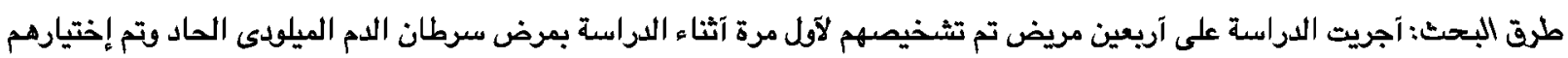

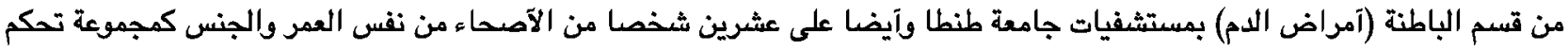

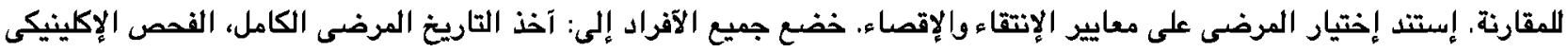

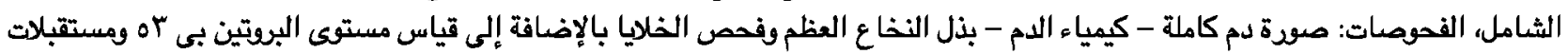
عامل نمو البشرة بإستخدام الإليزا .

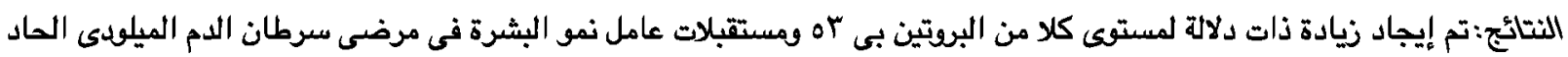

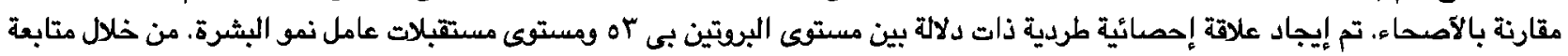

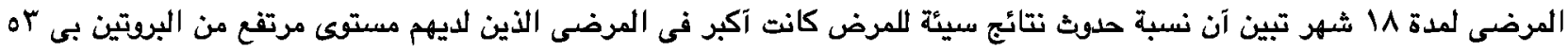

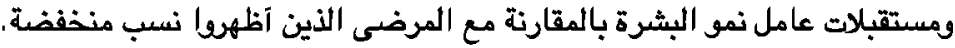

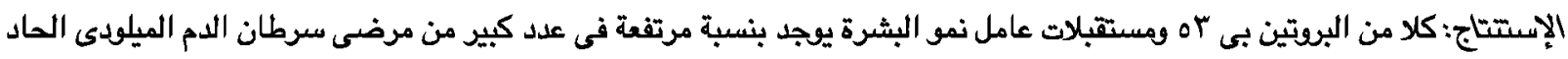

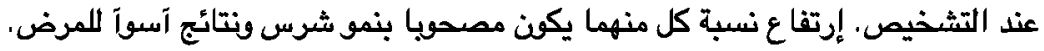

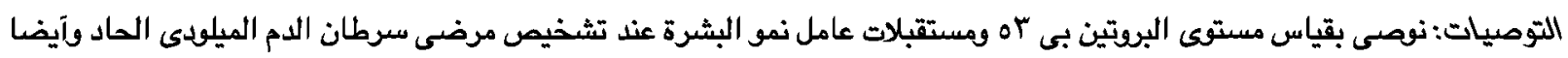

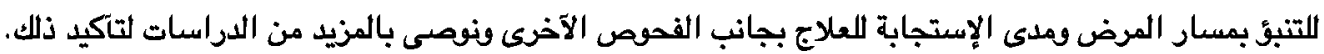

